\title{
New Plant Records for Manitoba
}

by G. A. Stevenson, Experimental Farm, Brandon

On September 26, 1962, Abutilon theophrasti Medic (G. Stevenson No. 2812) was collected in a garden at 855-12th Street, Brandon, where it had been introduced, it is believed, with vegetable seeds which came from Germany. There appears to be no previous record of this species for Manitoba. It has been collected in Ontario, Quebec and Prince Edward Island and according to Breitung (1957) there is a collection from Biggar in the University of Saskatcewan. It has been reported also from Nova Scotia and British Columbia. Stevens (1950) recorded it from three locations in North Dakota.

Abutilon theophrasti (Velvet Leaf or Pie Makers) is a tall, coarse, weedy, annual plant with rather inconspicuous deep yellow flowers and very large, velvety, heart-shaped leaves, and generally speaking resembles the common garden hollyhock to which it is related. The seeds are quite large and have been known to retain their viability for 50 years. Since this species is native to India and normally prefers the warmer regions of the world it is not likely to become a problem in the Prairie Provinces.

Melissa officionalis L. (G. Stevenson No. 2777) was collected on wasteland at Brandon on August 9, 1962. In Canada it has been reported only from Ontario and British Columbia but it is fairly common in the eastern and southern United States where it has escaped from cultivation. Generally speaking the plant resembles common mint, Mentha arvensis, but the leaves are broader and more coarsely crenate and the flowers are almost white. It has a variety of common names the most appropriate or descriptive of which is Lemon Balm, for the leaves when crushed are distinctly lemon-scented. The leaves may be steeped for a delicate aromatic drink, and the tender sprays and young leaves are used in salads and fruit caps. This savory herbwhich is mentioned by the Greek and Roman poets-has been grown in Old World gardens since ancient times.

Plantago coronopus L. (G. Stevenson No. 2828) was collected on October 3,1962 , in the clover introduction nursery where it had been introduced, presumably, with seed of Trifolium resupinatum which came from Portugal. This collection appears to be the first Canadian record. It has been found in the United States and according to Gray's Manual of Botany (1950) it occurs sporadically about ports but does not persist. Clapham, Tutin and Warburg (1952) gave its distribution as:- "Coasts of C. and S. Europe from S. Sweden, N. Africa, W. Asia, Azores; introduced in N. America, Australia and New Zealand." It is found in the British Isles and according to Ray (1586) it was cultivated in England 400 years ago. Vilmorn (1883) included it in his list of French vegetables. Apparently the long, narrow, ccarsely pinnatifid thickish leaveswhich account for one of the plant's common names, Buck's Horn Plantain -were used in salads. I have tasted the leaves on several occasions and have not found them at all palatable. One man's meat is another man's poison!

Specimens have been deposited in the Phanerogamic Herbarium, Plant Research Institute (DAO), Ottawa, and in the herbarium at the Experimental Farm, Brandon. Dr. Bernard Boivin, Plant Research Institute, Ottawa, kindly checked all specimens.

\section{LITERATURE CITED}

Breitung, A. G. Annotated Catalogue of the Vascular Flora of Saskatchewan. Amer. Midland Nat. 58:1-72, 1957.

Clapham, A. R., Tutin, T. G. and Warburg, E. F. Flora of the British Isles. Cambridge University Press, 1952.

Fernald: M. L. Gray's Manual of Botany. New rork, 1950.

Ray. Hist. PI. 879, 1586.

Stevens, O. A. Handbook of North Dakota Plants. Fargo, 1950.

Vilmorn. Les Pls. Potag. 169. 1883: 